\title{
Differences in Etiology Affect Mefenoxam Efficacy and the Control of Pink Rot and Leak Tuber Diseases of Potato
}

\author{
Raymond J. Taylor, Bacilio Salas, and Neil C. Gudmestad, Department of Plant Pathology, North Dakota State \\ University, Fargo 58105
}

\begin{abstract}
Taylor, R. J., Salas, B., and Gudmestad, N. C. 2004. Differences in etiology affect mefenoxam efficacy and the control of pink rot and leak tuber diseases of potato. Plant Dis. 88:301-307.

Data supplementing a previously published survey of North American isolates of Phytophthora erythroseptica and Pythium ultimum demonstrated that the proportion of the populations sensitive to mefenoxam remains high, 79.6 and $96.9 \%$ with $\mathrm{EC}_{50}$ sensitivities ranging from $<0.01$ to $0.9 \mu \mathrm{g} \mathrm{ml}^{-1}$ and $<0.01$ to $0.8 \mu \mathrm{g} \mathrm{ml}{ }^{-1}$, respectively. Mefenoxam should provide control of these pathogens in most potato production areas. Factors affecting the development of pink rot and leak in potato tubers and the efficacy of mefenoxam to control these diseases with different etiologies were examined. Results confirmed that $P$. erythroseptica is capable of directly infecting potato tubers causing pink rot, whereas Pythium ultimum requires a wound to infect and cause leak. Mefenoxam was applied to replicated field plots as a single in-furrow application at planting, as an in-furrow application at planting followed by an additional sidedress application 3 weeks after planting, as a single foliar application when tubers were 7 to $8 \mathrm{~mm}$ in diameter, and as two foliar applications when the tubers were 7 to $8 \mathrm{~mm}$ in diameter and 14 days later. The recommended label rate plus two additional lower application rates were used with each method. For tubers challenge-inoculated after harvest, mefenoxam was found to be more effective in controlling pink rot relative to leak over all application methods. The greatest level of pink rot control $(89 \%)$ was attained with the in-furrow at planting and sidedress application. All rates tested provided similar levels of control with this application method, but this method provided only a modest level of leak control (35\%), and leak was not controlled by foliar applications of mefenoxam at any rate tested. In contrast, the foliar applications of mefenoxam resulted in 10 to $50 \%$ control of pink rot. Since the isolates of both pathogens were highly sensitive to mefenoxam, disease-specific control was attributed to differences in disease etiology. Therefore, the use of mefenoxam to control pink rot in the field and storage appears to be well founded.
\end{abstract}

Additional keywords: metalaxyl, Ridomil Gold EC, Solanum tuberosum, Ultra Flourish EC, water rot

Pink rot and leak are ubiquitous soilborne diseases of potato (Solanum tuberosum L.) tubers. Either of these "water rot" diseases may be found during or immediately following harvest and can be an especially serious problem under conditions of high soil moisture, such as in areas with poor drainage soils or during periods of extended rainfall late in the season $(7,9)$. Pink rot and leak can be distributed widely within potato fields and storage facilities, and under favorable conditions, they may result in severe yield losses both before and after harvest $(2,9,18,22)$. As the common collective name implies, water rot symptoms for both diseases are similar,

Corresponding author: Neil C. Gudmestad E-mail: Neil.Gudmestad@ndsu.nodak.edu

Current address of Bacilio Salas: Department of Plant Pathology, University of Minnesota, St. Paul 55108.

Accepted for publication 18 November 2003.

Publication no. D-2004-0114-01R

(C) 2004 The American Phytopathological Society with the end result being a watery breakdown of infected tuber tissue, but certain differences in symptomatology are diagnostic for each disease. Potato tuber tissue affected by pink rot, caused by Phytophthora erythroseptica Pethybr., remains relatively firm and turns a distinct pink color when exposed to air for a short period of time (7). Tuber tissue affected by leak, caused primarily by Pythium ultimum Trow, is generally smoky gray to black in color, eventually becomes soft and watery, followed by a rapid loss of turgidity and structure $(3,9)$.

Both pathogens are endemic to most soils and are able to survive in infected plant tissue or debris, or for many years as oospores. Pythium ultimum has an extensive host range, causing root rots and seedling damping-off on a variety of host species in addition to potato (19). $P$. erythroseptica also has the ability to infect other solanaceous hosts, as well as many nonsolanaceous species (11). This pathogen usually infects potato tubers through the stolons, but may also gain entry through the eyes or lenticels via zoospores $(12,17,22)$. Since Pythium ultimum is not capable of penetrating undamaged periderm tissue, infection occurs almost exclusively through wounds $(8,19)$. $P$. erythroseptica also infects tubers through cuts, cracks, or other wounds made during harvest operations (21).

Strategies used to manage water rots are generally directed toward reducing conditions that favor infection and disease development. These are usually cultural in nature, and involve such practices as crop rotation, planting the crop in well-drained soils, avoiding excessive irrigation at the end of the growing season, allowing sufficient time between vine killing and harvest for proper periderm development, modifying tuber handling procedures to reduce wounding, and harvesting when tuber pulp temperatures are below $21^{\circ} \mathrm{C}(11,18$, 19,22). Mefenoxam (Ridomil Gold EC and Ultra Flourish EC) is the only fungicide currently used to control pink rot and leak $(14,15,18,22,25,28,29)$. Since its introduction as metalaxyl in the late 1970 s, this phenylamide fungicide has been used effectively against a wide range of fungi in the Peronosporales. Although resistance to mefenoxam has been found in populations of $P$. erythroseptica and Pythium ultimum $(6,10,24)$, the fungicide still provides reliable control of water rot diseases $(14,15)$. The effectiveness of mefenoxam, particularly in the case of pink rot, has precluded efforts to develop resistant cultivars. Some cultivars are less severely affected by $P$. erythroseptica and Pythium ultimum, but most commonly grown cultivars are susceptible to the pathogens (20). As a result, resistance is not commonly used as a means of controlling these water rots. Additional research is needed to assess the use of mefenoxam because it is pivotal in managing pink rot and leak $(18,22,25$, 28,29).

Studies have shown that the quantity of mefenoxam in tuber tissue varies greatly with standard application rates $(1,4)$. Concentrations of the fungicide localized at or near the periderm can be as much as twice that of the inner pulp cortex or medullary tissues (4). Therefore, protection offered by mefenoxam is often restricted to the area just beneath the periderm. It is possible that reduced efficacy of mefenoxam may result if the fungicidal barrier in the outer layers of tissues is disrupted or breached. Alternatively, any apparent difference in fungicidal control of these diseases could be due to differences in me- 
fenoxam sensitivity within the pathogen populations. The current study was undertaken to examine the relationship between disease etiology and fungicide effectiveness as it relates to development and control of potato water rots. Experiments were conducted to determine whether there is a rate response among treatment methods with fungicide application rates below the product label rates. Additional experiments were performed to reconfirm that Pythium ultimum is exclusively a wound pathogen and that $P$. erythroseptica can infect potato tubers directly under the inoculation conditions used to conduct these studies.

\section{MATERIALS AND METHODS}

Survey of mefenoxam sensitivity in the pathogen populations. A broad survey of the P. erythroseptica and Pythium ultimum populations in North America was conducted during the years 1998 to 2001 to determine the range of mefenoxam sensitivity in the portions of the populations of both pathogens considered to be sensitive to the fungicide (24). Data collected in 2001 supplemented information from this survey. Tubers with water rot symptoms were collected from commercial potato fields and storages in 16 states and $2 \mathrm{Ca}$ nadian provinces. Small pieces $(4 \times 4 \mathrm{~mm})$ of infected tissue were transferred to petri dishes containing water agar amended with ampicillin $\left(100 \mu \mathrm{g} \mathrm{ml}^{-1}\right)$ and incubated in the dark at 17 to $20^{\circ} \mathrm{C}$ for 3 to 5 days. Colonies with mycelia resembling those of P. erythroseptica or Pythium spp. were selected and purified by hyphal tipping. Isolates of $P$. erythroseptica and Pythium ultimum were identified based on, respectively, morphological characteristics of Stamps et al. (23) and a published key (26). Prior to screening for fungicide sensitivity, isolates of $P$. erythroseptica were maintained on clarified V8 juice agar medium $(10 \% \mathrm{~V} 8$ juice filtered through four layers of cheesecloth, $0.1 \% \mathrm{CaCO}_{3}$ and $2 \%$ agar), while those of Pythium spp. were kept on corn meal agar. All isolates of Pythium ultimum were inoculated onto potato tubers to confirm pathogenicity to potato prior to mefenoxam sensitivity testing.

Mefenoxam (Ridomil Gold 4EC) sensitivity was determined in vitro using a method similar to one described previously (24). Tests were conducted on modified V8 juice agar (5\% V8 juice filtered through four layers of cheesecloth and 2\% agar) amended with fungicide in a 10 -fold dilution series ranging from 0.01 to $100 \mu \mathrm{g} \mathrm{ml}^{-1}$. Disks, $5 \mathrm{~mm}$ in diameter, were cut from the margin of actively growing colonies of 4- to 6-day-old cultures of P. erythroseptica and positioned in the center of a $9-\mathrm{cm}$ culture dish with the mycelium in contact with the medium. Each dish contained 17 $\mathrm{ml}$ of amended medium and testing was done in duplicate at each concentration. The isolates of Pythium ultimum were tested in the same manner except that 2day-old cultures were used. A total of 1,099 isolates of $P$. erythroseptica and 415 isolates of Pythium ultimum were tested in this manner.

The growth response of each $P$. erythroseptica isolate was determined by measuring colony diameters in two perpendicular directions on each culture plate after 6 days of incubation in the dark at $20^{\circ} \pm$ $1^{\circ} \mathrm{C}$. Isolates of Pythium ultimum were tested under identical conditions except that colony measurements were made after a 36-h incubation period. Measurements were averaged, the diameter of the mycelial plug was subtracted, and relative growth reduction for each rate of fungicide was calculated as follows: [100 - (growth with fungicide/growth in control plate) * 100]. The concentration causing 50\% reduction of mycelial growth $\left(\mathrm{EC}_{50}\right)$ relative to the control was estimated by plotting the percent inhibition against the log-scale of fungicide concentration (24). Two independent trials were conducted to determine the $\mathrm{EC}_{50}$ values.

Wounding and disease incidence. Russet Norkotah, a potato cultivar susceptible to both diseases (20), was grown under center pivot irrigation using standard cultural practices of the region. The crop was grown without mefenoxam treatments. Tubers were harvested at maturity then stored for 2 weeks under $90 \%$ relative humidity $\left(15^{\circ} \mathrm{C}\right)$ to facilitate wound healing. Any tubers with symptoms of pink rot or leak were discarded. Test tubers were stored at $10^{\circ} \mathrm{C}$ for 3 months prior to testing. Prior to inoculation, disease-free tubers (140 to $190 \mathrm{~g}$ ) with apical eyes free of soil and periderm that was intact were acclimated at room temperature (20 to $25^{\circ} \mathrm{C}$ ) for 1 to 2 days.

Results from a preliminary study indicated that surface sterilization does not affect frequency of infection (20), so tubers were not washed or sterilized prior to inoculation. Inoculum preparation and application methods were similar to those used in earlier studies $(20,24)$. Nonwounded tubers were inoculated on apical eyes and wounded tubers were inoculated in an area $(1 \times 1 \mathrm{~cm})$ where the periderm was removed manually by abrasion with a no. 96 general-purpose, commercially available abrasive pad. Isolates of $P$. erythroseptica (266-2) and Pythium ultimum (153-7) previously determined to be pathogenic were used in this inoculation study (20). Isolate pathogenicity was maintained via inoculation of cv. Russet Burbank tubers and reisolation on water agar culture medium.

Zoospores of $P$. erythroseptica were obtained using a procedure based upon a technique described by Vujicic and Colhoun (27), but clarified V8 juice agar (100 $\mathrm{ml}$ of clarified V8 juice, $15 \mathrm{~g}$ of agar, 900 $\mathrm{ml}$ of deionized $\mathrm{H}_{2} \mathrm{O}$ ) and clarified $\mathrm{V} 8$ juice broth (100 $\mathrm{ml}$ of clarified V8 juice,
$900 \mathrm{ml}$ of deionized $\mathrm{H}_{2} \mathrm{O}$ ) were substituted for pea extract medium. The clarified V8 juice was prepared by filtering standard V8 juice through four layers of cheesecloth. Isolate 266-2 was grown on culture plates containing clarified V8 juice agar at ambient temperature $\left(20\right.$ to $\left.25^{\circ} \mathrm{C}\right)$. After 3 days, 5-mm-diameter mycelial disks were cut and placed in petri plates containing autoclaved clarified V8 broth. These plates were incubated in the dark at ambient temperature $\left(20\right.$ to $\left.25^{\circ} \mathrm{C}\right)$ for 3 days. The clarified V8 juice broth was decanted from the plates, and after rinsing the mycelial mats two or three times with sterile deionized $\mathrm{H}_{2} \mathrm{O}, 10 \mathrm{ml}$ of autoclaved, filtered soil extract from a potato field (10\%) were added to each plate. Sporangial formation occurred after 36 to $48 \mathrm{~h}$ incubation under continuous light (eight Sylvania F20T12/ CW lamps) in an environmentally controlled incubator $\left(20 \pm 1^{\circ} \mathrm{C}\right)$. Zoospore release was stimulated by chilling cultures at $10 \pm 1^{\circ} \mathrm{C}$ for $1 \mathrm{~h}$ followed by a warming period at 20 to $25^{\circ} \mathrm{C}$. Inoculum concentration was determined with a hemacytometer and adjusted to $2 \times 10^{4}$ zoospores per milliliter. Zoospore suspensions were held in the dark at 8 to $10^{\circ} \mathrm{C}$ until inoculations were made, generally within 10 to $60 \mathrm{~min}$.

For the inoculations with $P$. erythroseptica, tubers were placed in plastic moist chamber boxes $(33 \times 24 \times 12 \mathrm{~cm})$ lined at the bottom with no. 3 plastic mesh. Nonwounded tubers were inoculated with $10 \mu \mathrm{l}$ of the zoospore suspension (approximately 200 zoospores) on each of three apical eyes. Wounded tubers received a single 10$\mu \mathrm{l}$ aliquot of inoculum in the center of the abraded area. Inoculated tubers were covered with four layers of paper towels moistened to saturation with deionized water. The chamber boxes were sealed to establish high humidity to promote infection. The chambers were incubated in the dark at ambient temperature of 20 to $22^{\circ} \mathrm{C}$ for 10 days.

The Pythium ultimum isolate was grown on modified V8 juice agar $(100 \mathrm{ml}$ of $\mathrm{V} 8$ juice, $1.25 \mathrm{~g}$ of $\mathrm{CaCO}_{3}, 15 \mathrm{~g}$ of agar, 900 $\mathrm{ml}$ of deionized $\mathrm{H}_{2} \mathrm{O}$ ) for $48 \mathrm{~h}$ at 20 to $22^{\circ} \mathrm{C}$. Pythium-colonized $5 \mathrm{~mm}$ diameter agar plugs were cut from the margin of the culture and immediately pressed onto an apical eye of a nonwounded tuber, or placed in the center of the abraded area of a wounded tuber (1 plug per tuber, mycelium side down). All inoculated tubers were placed in plastic moist chamber boxes and incubated as described above.

Leak development was assessed 6 days after inoculation, and pink rot was evaluated on day 10. Disease incidence was assessed by cutting the inoculated tubers and examining internal tissue for the development of a pink color characteristic of pink rot infection or watery, black discoloration diagnostic of leak. To evaluate pink rot, tubers were bisected longitudinally from the apical to basal end. Tubers inocu- 
lated with Pythium were bisected through the point of inoculation, perpendicular to the longitudinal axis. In order to enhance development of the color characteristic of infected tissue, cut tubers were covered with paper towels saturated with tap water and held at 20 to $22^{\circ} \mathrm{C}$ for $30 \mathrm{~min}$ prior to evaluation. The number of tubers infected was recorded and disease incidence was calculated as [(number of infected tubers/number of inoculated tubers) $\times 100$ ] Representative symptomatic tubers occasionally were selected at random and isolations made onto water agar to confirm the identity of the pathogens. The experiment was run as a single trial consisting of 10 tubers per treatment with each treatment replicated four times in a completely random design.

Field trials: Rate and method of mefenoxam application. Fungicide application trials were conducted under center pivot irrigation near Park Rapids, MN, during the 2000, 2001, and 2002 growing seasons. Test plots were managed by the cooperating grower using agronomic practices typical of those recommended for irrigated potato production in the region. Plots, located in designated sections of commercial potato production fields, were planted on 5 May 2000, 2 May 2001, and 29 April 2002 using certified seed of cv. Russet Burbank obtained from seed potato producers in North Dakota. Although fungicide trials were conducted in the field over three successive seasons, postharvest challenge-inoculation experiments were not carried out in 2001 because yields that year were too low to provide the quantity of acceptable tubers required. Mefenoxam (Ridomil Gold 4EC) was applied to replicated field plots either as a single infurrow application of $200 \mathrm{~g}$ a.i. ha $\mathrm{ha}^{-1}$ at planting, or as a single foliar application of $100 \mathrm{~g}$ a.i. ha ${ }^{-1}$ when tubers were 7 to $8 \mathrm{~mm}$ in diameter, and as two foliar applications of $100 \mathrm{~g}$ a.i. ha ${ }^{-1}$ when the tubers were 7 to $8 \mathrm{~mm}$ tuber size and 14 days later using Ridomil Gold Bravo 76.5 WG. A fourth label-approved method not currently widely practiced, in-furrow application of $200 \mathrm{~g}$ a.i. ha ${ }^{-1}$ at planting followed by an additional sidedress application of $100 \mathrm{~g}$ a.i. ha ${ }^{-1} 3$ weeks after planting, also was included for comparative purposes. The application rates used with these methods were within $1.5 \%$ of recommended label rate. Additional applications of 75 and $50 \%$ of the recommended rates also were used with each method (Table 1). A separate untreated control was paired with each application method. Treatments applied to single rows $9.1 \mathrm{~m}$ long were replicated six times in a split plot, split block randomized complete block design for all application methods.

Postharvest inoculation and disease evaluation. Tubers were stored and prepared for inoculation according to the procedures applied in the wounding study described above. Isolates PR347 and 266-2 of $P$. erythroseptica were used in 2000 and 2002, respectively. Isolate 153-7 of $P y$ thium ultimum was used in 2000 and 2002. These isolates were previously determined to be pathogenic and highly sensitive to mefenoxam $\left(\mathrm{EC}_{50}<0.05 \mu \mathrm{g} \mathrm{ml}^{-1}\right)$. Inoculation techniques were identical to those used in the wounding study except that $P$. erythroseptica only was inoculated to apical eyes and Pythium ultimum only was inoculated to areas $(1 \times 1 \mathrm{~cm})$ of the periderm manually wounded by abrasion. Disease incidence was determined as described in the wounding study above.
Experimental design and statistical analysis of postharvest challenge inoculations trials. The factorial of method (infurrow at planting, in-furrow at planting plus sidedress, one foliar application, two foliar applications) by mefenoxam rate $4 \times$ 4 was arranged in a randomized block design with six replications. Application method was the main blocking factor and split plots consisted of mefenoxam rates. Test tubers were selected at random from each of the six field treatment replications. A total of 240 tubers (40 per treatment per replication) were used in the inoculation studies.

Table 1. Methods and rate of application of mefenoxam in the 2000, 2001, and 2002 field experiments

\begin{tabular}{llc}
\hline Fungicide & Application method and timing & $\begin{array}{c}\text { Application } \text { rate }^{\mathbf{z}} \\
\text { (g a.i. ha }^{\mathbf{- 1}} \text { ) }\end{array}$ \\
\hline Control & In-furrow at planting & 0 \\
Ridomil Gold EC & In-furrow at planting & 100 \\
Ridomil Gold EC & In-furrow at planting & 150 \\
Ridomil Gold EC & In-furrow at planting & 200 \\
Control & At planting + 21 days (sidedress) & 0 \\
Ridomil Gold EC & At planting + 21 days (sidedress) & 200 \\
Ridomil Gold EC & At planting + 21 days (sidedress) & 250 \\
Ridomil Gold EC & At planting + 21 days (sidedress) & 300 \\
Control & At 7-8 mm sized tubers & 0 \\
Ridomil Gold Bravo 76.5 WG & At 7-8 mm sized tubers & 50 \\
Ridomil Gold Bravo 76.5 WG & At 7-8 mm sized tubers & 75 \\
Ridomil Gold Bravo 76.5 WG & At 7-8 mm sized tubers & 100 \\
Control & At 7-8 mm sized tubers + 14 days & 0 \\
Ridomil Gold Bravo 76.5 WG & At 7-8 mm sized tubers + 14 days & 100 \\
Ridomil Gold Bravo 76.5 WG & At 7-8 mm sized tubers + 14 days & 150 \\
Ridomil Gold Bravo 76.5 WG & At 7-8 mm sized tubers + 14 days & 200 \\
\hline
\end{tabular}

${ }^{\mathrm{z}}$ Highest rate is within $1.5 \%$ of recommended label rate for each application method.
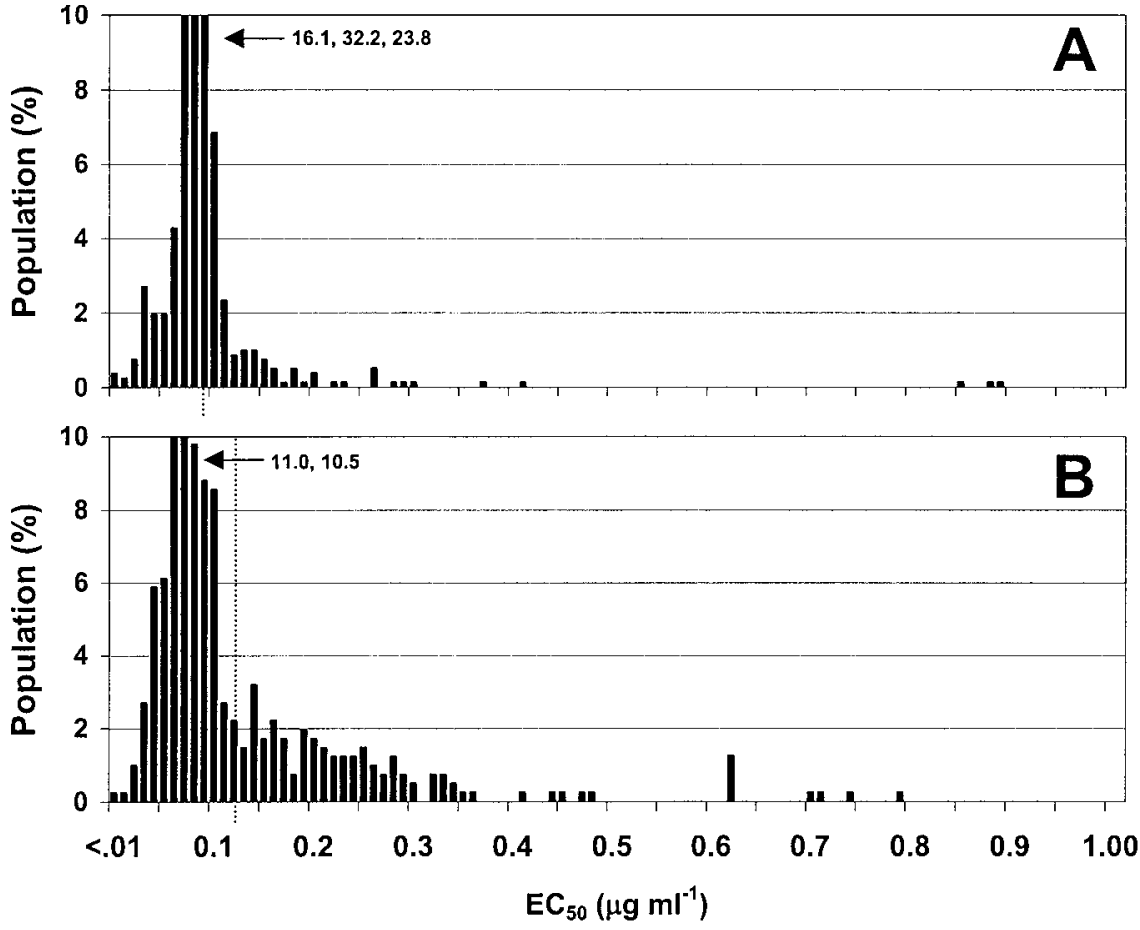

Fig. 1. Frequency distribution of mefenoxam sensitivity of 820 isolates of Phytophthora erythroseptica, A, and 402 isolates of Pythium ultimum, B, collected in North America from 1998 to 2001. (Broken lines indicate population means: $\mathrm{A}=0.0876, \mathrm{~B}=0.1246$; values above the $10 \%$ line indicated by arrows). 
Variance homogeneity was determined using the method of Levene (13). After variance homogeneity testing was completed, disease incidence data were combined for analysis of variance using the General Linear Model of the Statistical Analysis System (PROC GLM, SAS Institute, Cary, NC). The inoculation experiments were repeated once in 2000 and twice in 2002 with approximately a 2- to 3 -week interval between trials. Mean separation of method $\times$ rate interactions with orthogonal, single degree of freedom comparisons was accomplished using PROC MIXED with the option of DIFF (SAS Institute). Disease incidence for each pathogen also was transformed to percent disease control using the formula [(Disease incidence of paired untreated control disease incidence of treatment)/disease incidence of paired untreated control $x$ 100]. Disease control data were generated for comparative purposes only and were not subjected to statistical analysis.

\section{RESULTS}

Sensitivity of $P$. erythroseptica and $P y$ thium ultimum to mefenoxam. Over the survey period, $79.7 \%$ of the P. erythroseptica isolates and $96.9 \%$ of the Pythium ultimum isolates were found to be sensitive to mefenoxam. Sensitivities in these populations remain high. In the final year of the study, 93.1 and $99.1 \%$ of the $P$. erythroseptica and Pythium ultimum isolates, respec-

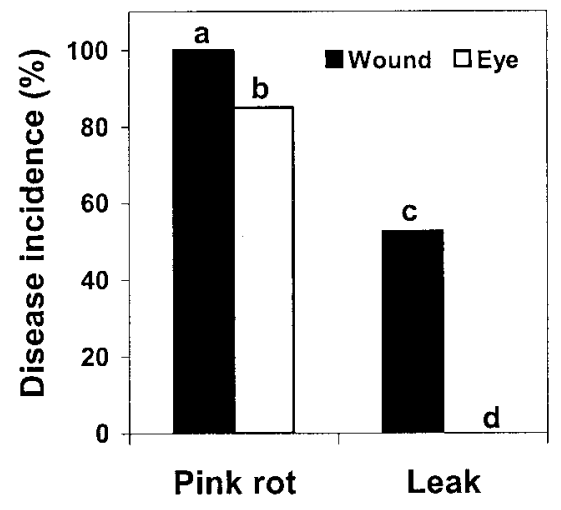

Fig. 2. Effect of wounding on disease incidence of nontreated tubers inoculated with Phytophthora erythroseptica (pink rot) and Pythium ultimum (leak). Treatment means with the same letters are not significantly different $(P=0.05)$. tively, collected were sensitive. A total of 820 mefenoxam-sensitive isolates of $P$. erythroseptica and 402 mefenoxamsensitive isolates of Pythium ultimum were recovered and characterized during the 4year survey. Sensitivity of $P$. erythroseptica, expressed as $\mathrm{EC}_{50}$, ranged from $<0.01$ to $0.9 \mu \mathrm{g} \mathrm{ml}^{-1}$ with a mean $\mathrm{EC}_{50}$ value of $0.0876 \mu \mathrm{g} \mathrm{ml}^{-1}$ (Fig. 1A). The range of $\mathrm{EC}_{50}$ values for sensitivity of Pythium ultimum to mefenoxam ranged from $<0.01$ to $0.8 \mu \mathrm{g} \mathrm{ml}^{-1}$ with a mean of $0.1246 \mu \mathrm{g}$ $\mathrm{ml}^{-1}$ (Fig. 1B).

Wounding and disease incidence. Both pathogens infected tubers under the conditions in this experiment, and disease incidence was pathogen and wound specific (Fig. 2). Incidence of pink rot (100\%) and leak $(52.5 \%)$ was highest in wounded tubers. Incidence was significantly lower $(85 \%)$ in the nonwounded tubers inoculated with $P$. erythroseptica at the apical eyes than in the wounded tubers. Pythium ultimum failed to infect nonwounded tubers through the eyes.

Field trials: Rate and method of mefenoxam application. The variances estimated for 28 of 32 treatments were determined to be homogeneous; therefore, data for 2000 and 2002 were combined for further analysis. Methods, rates of application, and the interaction were highly significant for both diseases (Table 2). Mefenoxam applied either as a single infurrow application at planting or at planting with a follow-up sidedress application significantly reduced the incidence of pink rot and leak compared with the two foliar application methods tested (Fig. 3). Application rate also markedly affected disease incidence. Although the incidence of both diseases was significantly reduced when mefenoxam was applied at either the recommended label rate or at $75 \%$ of the label rate, the level of reduction was greater for pink rot compared with leak and was generally more closely related to the quantity of mefenoxam applied (Fig. 4).

Rate and method of fungicide application affected disease development and control. The magnitude of these effects was related to disease etiology. Highly significant reductions in pink rot disease incidence were obtained when mefenoxam was applied in-furrow at planting, infurrow with follow-up sidedress, or as two foliar applications using the standard label rates (Fig. 5). Rate responses also were observed within each of these application methods, and mefenoxam applied in the

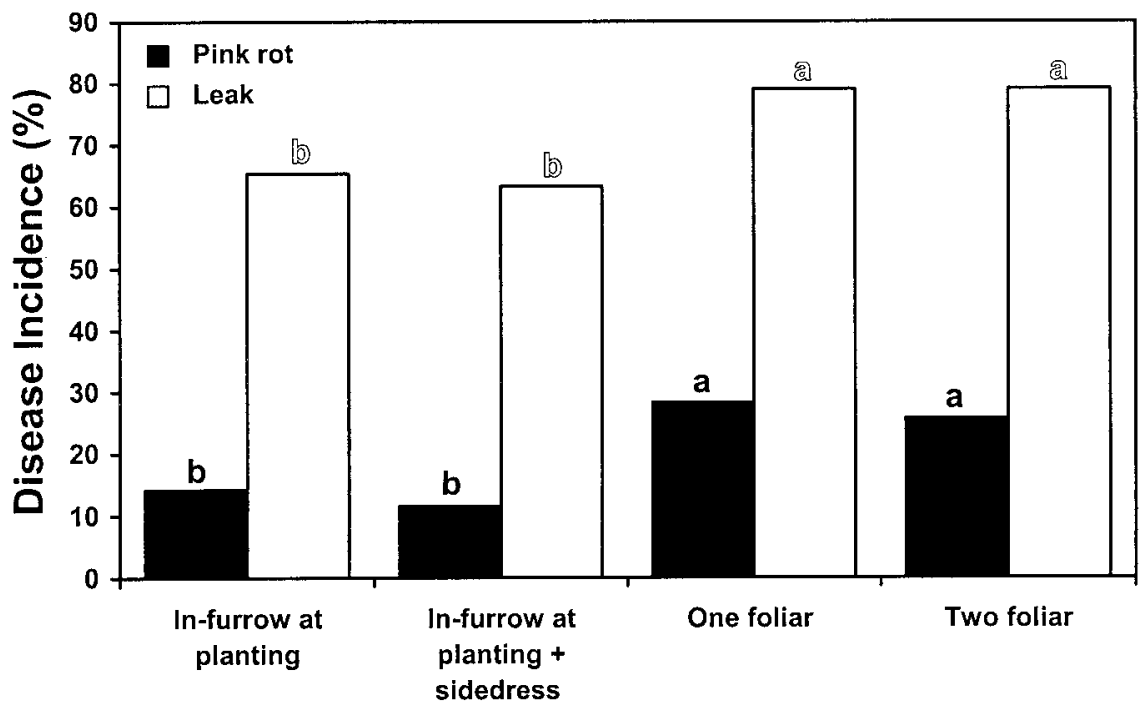

\section{Method of mefenoxam application}

Fig. 3. Effect of method of mefenoxam application on the incidence of pink rot and leak. Means with the same letter within each disease are not significantly different $(P=0.05)$.

Table 2. Combined analysis of variance for the effect of mefenoxam on the incidence of pink rot and leak in tubers from the 2000 and 2002 field trials challenge-inoculated with Phytophthora erythroseptica and Pythium ultimum

\begin{tabular}{|c|c|c|c|c|c|c|c|c|c|}
\hline \multirow[b]{2}{*}{ Source of variation $y$} & \multirow[b]{2}{*}{ df } & \multicolumn{2}{|c|}{ Incidence of pink rot } & \multirow[b]{2}{*}{$F$ value $^{\mathrm{z}}$} & \multirow[b]{2}{*}{$P>F$} & \multicolumn{2}{|c|}{ Incidence of leak } & \multirow[b]{2}{*}{$F$ value $^{z}$} & \multirow[b]{2}{*}{$P>F$} \\
\hline & & ss & ms & & & SS & ms & & \\
\hline Year & 1 & $26,601.69$ & $26,601.69$ & & & 822.01 & 822.02 & & \\
\hline Block (year) & 10 & $1,719.98$ & 171.99 & & & $5,742.09$ & 574.21 & & \\
\hline Method & 3 & $14,522.87$ & $4,840.96$ & $53.45^{* *}$ & 0.0001 & $15,812.04$ & $5,270.68$ & $23.72^{* *}$ & 0.0001 \\
\hline Rate $^{z}$ & 3 & $15,684.54$ & $5,228.18$ & $57.72^{* *}$ & 0.0001 & $5,152.80$ & $1,717.60$ & $7.73^{* *}$ & 0.0001 \\
\hline Method*rate ${ }^{z}$ & 9 & $4,389.37$ & 488.71 & $5.40^{* *}$ & 0.0001 & $6,203.04$ & 689.23 & $3.10^{* *}$ & 0.0032 \\
\hline Method*rate*block & 75 & $6,792.81$ & 90.57 & & & $16,665.17$ & 222.20 & & \\
\hline
\end{tabular}

y Significance tested using method*rate*block as an error term.

$\mathrm{z}^{* *}=$ significant at $P<0.01$. 
soil at recommended rates most effectively reduced pink rot disease incidence. Although a rate-specific trend toward less disease was associated with the single foliar application of mefenoxam, these reductions in pink rot incidence were not significant. All rates significantly reduced the incidence of pink rot with the in-furrow and in-furrow plus sidedress application methods, and these methods provided significantly greater reductions in disease incidence than the foliar applications when compared on a rate for rate basis. Pink rot incidences were not significantly different with application rates of 100,150 , or $200 \mathrm{~g}$ a.i. ha ${ }^{-1}$ when mefenoxam was applied infurrow at planting or when applied infurrow at planting followed by a sidedress at rates of 200, 250, or $300 \mathrm{~g}$ a.i. ha ${ }^{-1}$.

Although rate responses were observed with both foliar application methods, the number of foliar applications did not significantly affect pink rot disease incidence (Fig 5A). The label recommendation of two foliar applications of $100 \mathrm{~g}$ a.i. ha ${ }^{-1}$, for a total of $200 \mathrm{~g}$ a.i. $\mathrm{ha}^{-1}$ mefenoxam applied, did not significantly decrease disease incidence relative to a single foliar application at the rate of $100 \mathrm{~g}$ a.i. $\mathrm{ha}^{-1}$. A single foliar application of mefenoxam provided approximately $35 \%$ pink rot disease control compared with $50 \%$ control when the label recommendation of two foliar applications was used (Fig. 5B).

Leak incidence remained relatively high, at approximately $60 \%$, when mefenoxam was applied as either an in-furrow application at planting or in-furrow with an additional sidedress application (Fig. 6A). The incidence of pink rot ranged from 5 to $15 \%$ when the same application rates and methods were used (Fig. 5A), resulting in approximately 50 to $75 \%$ disease control (Fig. 5B). In contrast, these rates and methods resulted in approximately $20 \%$ leak disease control (Fig. 6B). Although modest, reductions in disease incidence were highly significant across all rates with the in-furrow application methods. Leak incidence was not significantly different at $100 \mathrm{~g}$ a.i. $\mathrm{ha}^{-1}$ from the recommended rate of $200 \mathrm{~g}$ a.i. ha- ${ }^{-1}$ in-furrow at planting. Increasing the rate to $300 \mathrm{~g}$ a.i. $\mathrm{ha}^{-1}$ with the planting plus sidedress application method also did not reduce the incidence of leak relative to the recommended rate. No rate of mefenoxam used with either foliar application method significantly reduced the incidence of leak. These results demonstrate that control of leak with mefenoxam was highly variable regardless of rate or method of application (Fig. 6B). Mefenoxam provided the best control of both water rot diseases when used as a combined furrow plus sidedress application at the highest rate, approximately $300 \mathrm{~g}$ a.i. ha ${ }^{-1}$. This treatment resulted in $88.8 \%$ control of pink rot and $34.1 \%$ control of leak (Figs. 5B and $6 B)$.

\section{DISCUSSION}

Populations of P. erythroseptica and $P y$ thium ultimum collected in North America during the 4-year survey (1998 to 2001) generally remained sensitive $\left(\mathrm{EC}_{50}<1.0\right.$ $\mu \mathrm{g} \mathrm{ml}{ }^{-1}$ ) to mefenoxam. Consequently, mefenoxam remains an effective control measure for pink rot and leak occurring in

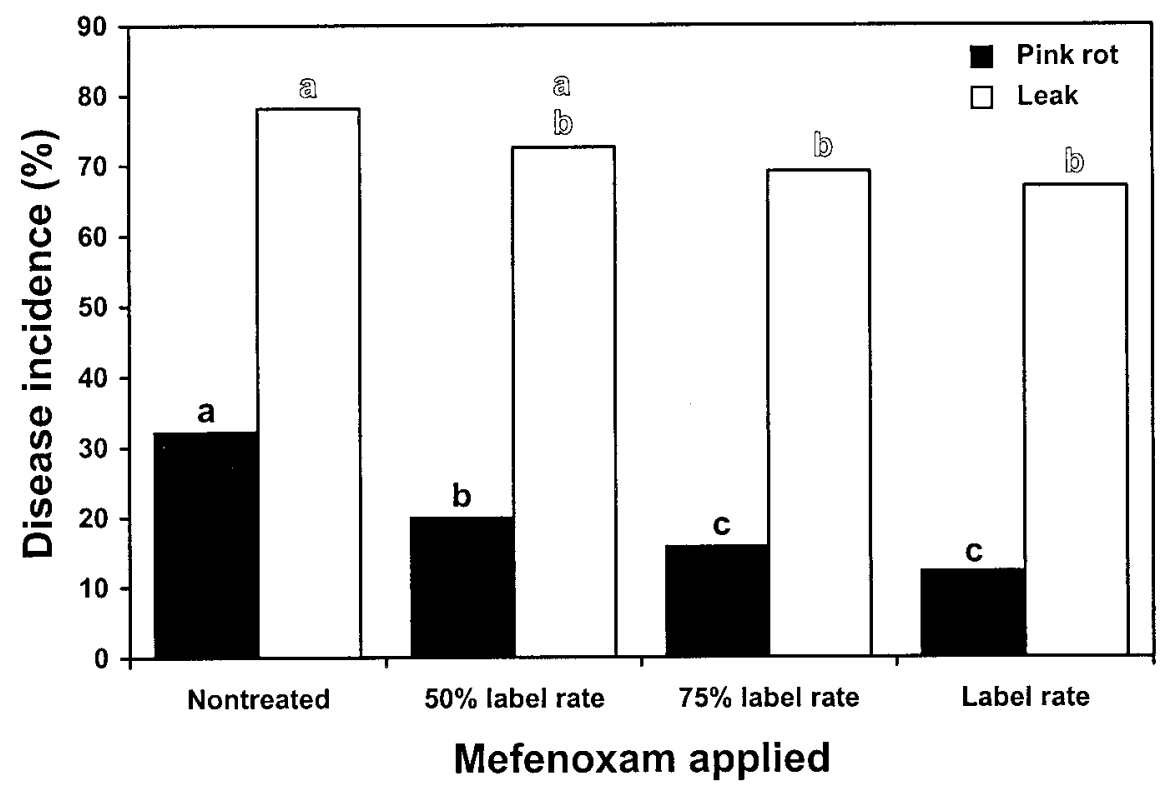

Fig. 4. Effect of rate of mefenoxam application on the incidence of pink rot and leak. Means with the same letter within each disease are not significantly different $(P=0.05)$.
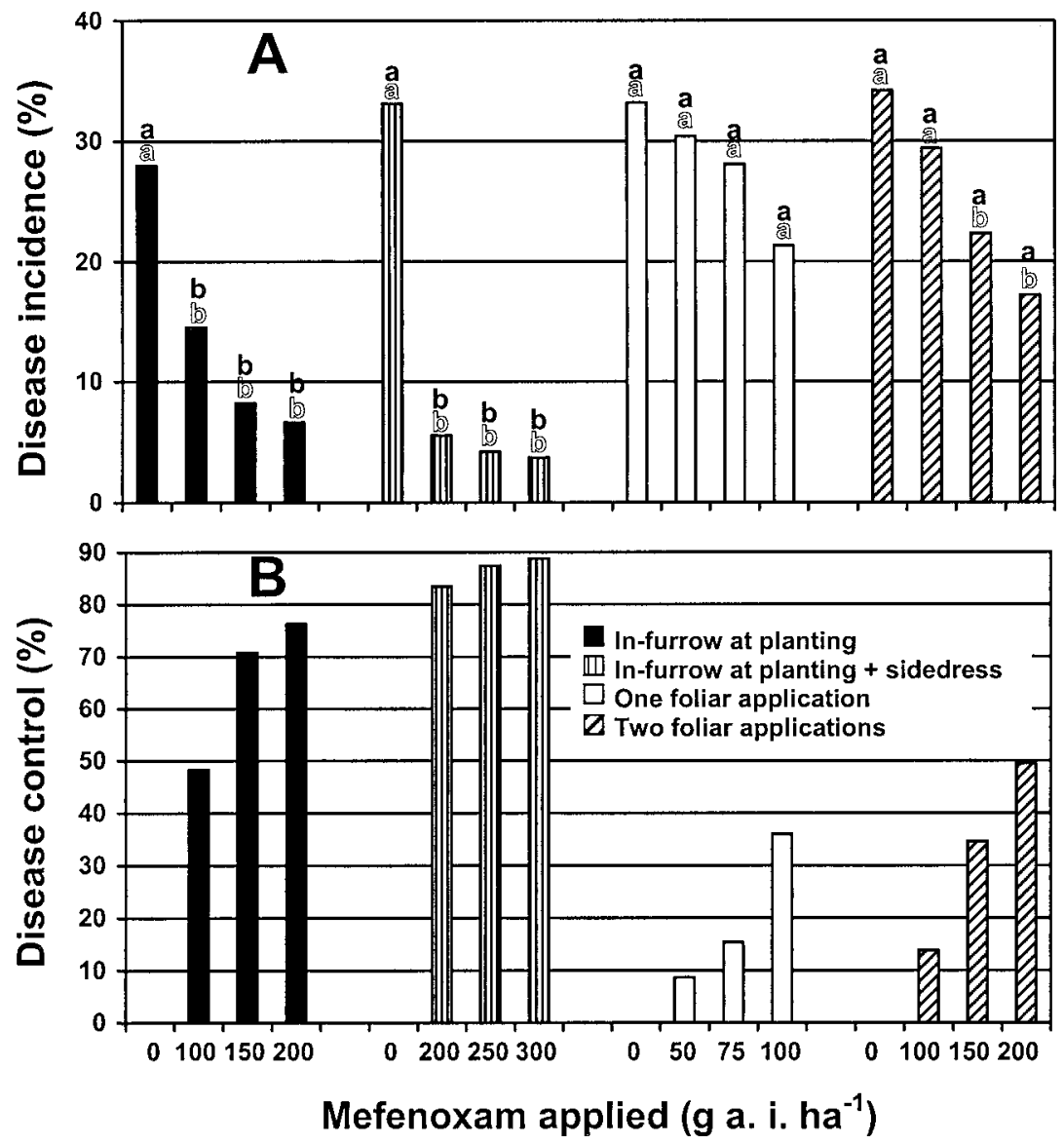

Fig. 5. Effect of mefenoxam application method and rate on $\mathbf{A}$, pink rot incidence and $\mathbf{B}$, disease control. Means with the same letter are not significantly different $(P=0.05)$. Outlined letters are for comparison of rates within a method of application. Solid letters are for comparison of specific rates among application methods. 
the field and storage in most potato production areas. Specific differences in the level of control attained with mefenoxam are likely attributable to differences in the pathogens' modes of infection since the proportion of each population sensitive to mefenoxam remains high and the ranges of populations are relatively similar (Fig. 1).

Results obtained in this study confirm that pink rot and leak differ in etiology $(8,12,17,19,22)$. The pink rot pathogen, $P$. erythroseptica, readily infects potato tubers through wounds and can cause disease by directly penetrating nonwounded tissue such as eyes. Pythium ultimum does not infect uninjured tuber periderm, so wounds are a prerequisite for infection and development of leak. These observations may explain differences in efficacy of mefenoxam in controlling pink rot and leak.

Mefenoxam has been reported to be symplastic, accounting for the effect that foliar applications of the fungicide have on potato tuber disease control. Early studies demonstrated the limited ambimobility of this chemistry relative to the rate applied to the foliage and the amount of residue detectable in the tuber $(1,4)$. Metalaxyl is not uniformly distributed throughout the tuber from outside (periderm) to the inside (corsensitivities of the sensitive isolates of both

tex, medullary tissue). The aforementioned studies determined the overall metalaxyl residue present in all potato tuber tissue to be in the range of 0.012 to $0.030 \mu \mathrm{g} \mathrm{ml}^{-1}$ $(1,4)$, well below the $\mathrm{EC}_{50}$ mean sensitivity of $P$. erythroseptica $\left(0.086 \mu \mathrm{g} \mathrm{ml}^{-1}\right)$ and $P$. ultimum $\left(0.12 \mu \mathrm{g} \mathrm{m} \mathrm{m}^{-1}\right)$. The level of metalaxyl in potato periderm was significantly higher than elsewhere in the tuber and determined to be in the range of 0.033 to $0.055 \mu \mathrm{g} \mathrm{g}^{-1}$ of tissue (4), much closer but still below the mean $\mathrm{EC}_{50}$ of either pathogen.

Based upon current information, it is only reasonable to hypothesize that significant differences in disease control would be achieved for each disease through the use of mefenoxam. This was shown to be the case in the present study. Compared to pink rot, less leak control was observed among all fungicide rates used with each method of application. In fact, with foliar applications of mefenoxam, we did not demonstrate a rate response in reducing infection incidence or disease control for leak. Two foliar applications of mefenoxam at the label rate $\left(200 \mathrm{~g}\right.$ a.i. $\left.\mathrm{ha}^{-1}\right)$ did not control leak; in contrast, pink rot incidence was significantly reduced with this rate and application method. Interestingly, a similar rate of mefenoxam applied
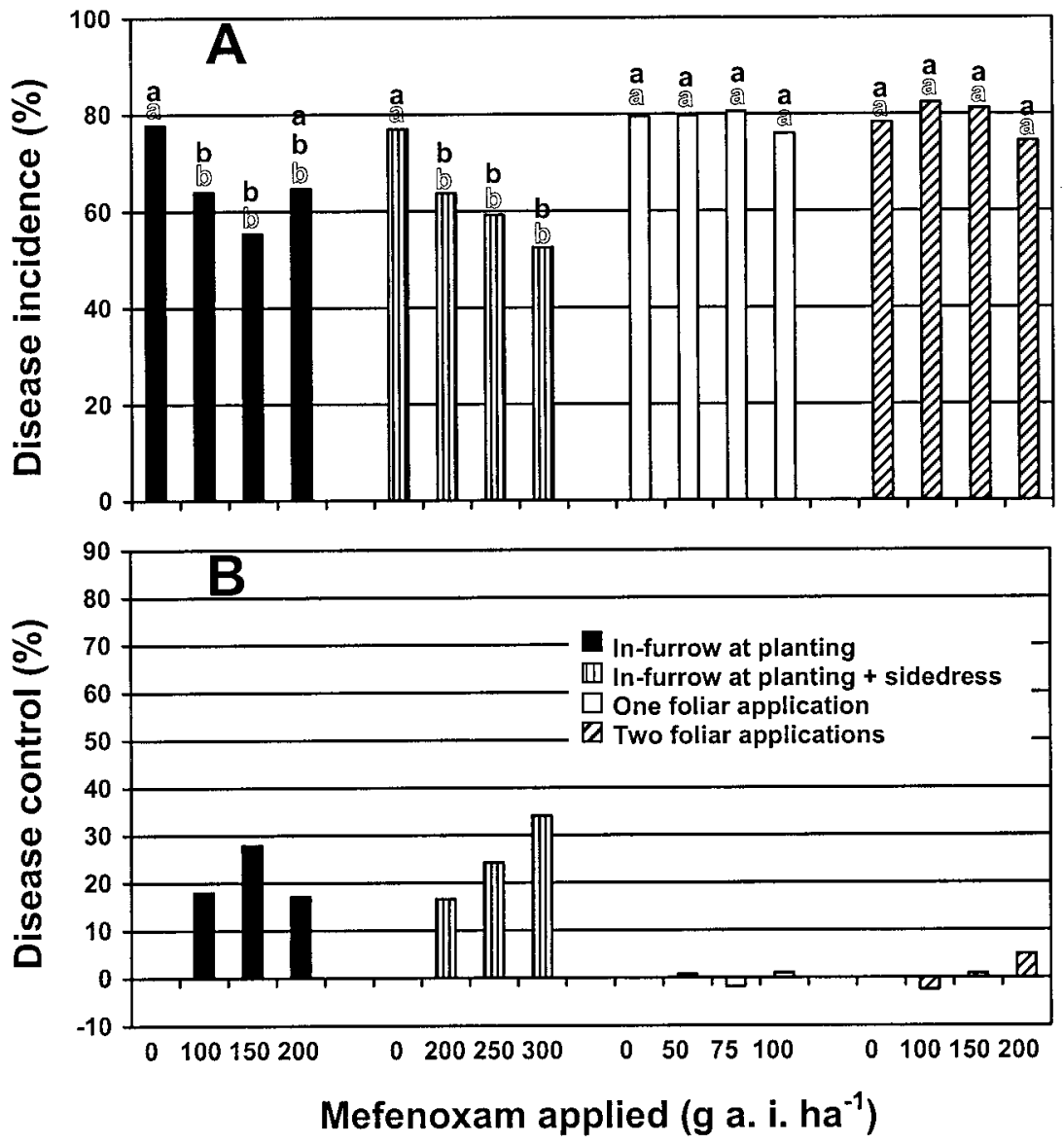

Fig. 6. Effect of mefenoxam application method and rate on $\mathbf{A}$, leak incidence and $\mathbf{B}$, disease control. Means with the same letter are not significantly different $(P=0.05)$. Outlined letters are for comparison of rates within a method of application. Solid letters are for comparison of specific rates among application methods. in-furrow at planting $\left(200 \mathrm{~g}\right.$ a.i. $\left.\mathrm{ha}^{-1}\right)$ provided some leak control, but it is questionable whether this level of disease control (ca. $17 \%$ ) is economically important. Clearly, the use of mefenoxam by potato producers for the sole purpose of controlling leak in potato tubers is questionable. Potato producers would probably achieve more effective control of leak by promoting good skin set prior to harvest, minimizing wounds during harvest operations, and avoiding tuber pulp temperatures above $21^{\circ} \mathrm{C}(19)$. Potato producers can also avoid the use of extremely susceptible cultivars in those instances where disease pressure is expected to be high (20).

Mefenoxam is the active R-enantiomer (94:3 ratio of $\mathrm{R}$ - to S-enantiomers) of the racemic mixture metalaxyl (50:50 ratio of $\mathrm{R}$ - to S-enantiomers). This chemistry was originally labeled for foliar applications only because of a perceived threat that infurrow applications at planting would significantly increase the risk of resistance development in Phytophthora infestans. With the migration of A2 mating types of $P$. infestans that possessed metalaxyl resistance out of Mexico in the late 1980s (5), phenylamide fungicide resistance management for late blight became a moot point. As a result, label changes on registered mefenoxam products in the late 1990 s included the application of the fungicide in-furrow during potato planting operations, resulting in significantly improved control of pink rot $(14,15,28)$, which was confirmed in this study. At the application rate of approximately $200 \mathrm{~g}$ a.i. $\mathrm{ha}^{-1}$, in-furrow applications provided superior control of pink rot and leak compared with foliar applications. Furthermore, pink rot control was enhanced with increasing rates of mefenoxam within each method of application. These results are supported by earlier studies demonstrating that increased rates of metalaxyl applied to the foliage significantly increased the detectable residue level in the potato tuber (4). These studies also validate the current label for mefenoxam on potato, which recommends an in-furrow application, a side-dressing prior to row closure, or two foliar applications for disease control. We have performed other studies in which a single well-timed application of mefenoxam at 7 to $8 \mathrm{~mm}$ tuber size provided sufficient control of pink rot (N. C. Gudmestad, unpublished), which is consistent with the results obtained by others (16). Potato growers often question whether disease control could be achieved with reduced rates of mefenoxam. Data presented here demonstrate that mefenoxam applications at less than the label recommended rate can compromise pink rot control since disease incidence was generally greater at the lower rates.

These studies support the utility of mefenoxam for the control of pink rot. The recommended label rates (ca. $200 \mathrm{~g}$ a.i. ha ${ }^{-1}$ ) 
are appropriate, since we obtained a response in $P$. erythroseptica infection rate inverse to the amount of mefenoxam applied within each method of application. In-furrow applications of mefenoxam at planting provide the most cost effective disease control compared with foliar applications. The use of mefenoxam by potato producers for the control of pink rot is warranted and supported by these studies and others $(14,15,28)$. The use of mefenoxam does not preclude the integration of other disease management tactics, however, especially considering that the pink rot fungus can infect wounds made during harvest under certain environmental conditions (21). Therefore, in addition to using mefenoxam, potato producers should implement the same tactics used to manage leak when dealing with pink rot.

Layby or sidedress application of mefenoxam during cultivation and hilling is currently included in the label recommendations, but this is not a widely used practice. The results of the present study demonstrate that mefenoxam application infurrow at planting coupled with a sidedress application is particularly effective in controlling both leak and pink rot. In fact, because the only reliable method of leak control we achieved during the course of these studies was through the combination of mefenoxam applied in-furrow and at sidedress, we feel that growers should give this method more serious consideration when planning their control strategies. This combination of application methods provided a definite rate response, one that was measurable and significant at each rate increment. It is probable that the rate response is attributable primarily to higher residues of mefenoxam being deposited in the tuber periderm and possibly the cortex. Sidedress application of mefenoxam is a method of application that should be investigated further since it is perhaps the only alternative producers may have in obtaining chemical control of a wound pathogen such as Pythium ultimum.

The studies reported here were performed using Russet Burbank, a cultivar moderately susceptible to pink rot (20). It is possible that results could differ with cultivar susceptibility. Additionally, resistance to this fungicide could become a compounding factor in controlling these diseases in the future. In order to design and develop alternative strategies to enhance the effectiveness and longevity of this fungicide, it is essential that future research address these issues.

\section{ACKNOWLEDGMENTS}

We thank Dean Peterson, Darryl Serfling, Dick Nilles, Josh Rohrer, Collin Auwarter, and Viviana Rivera for technical assistance in conducting these experiments.

\section{LITERATURE CITED}

1. Barak, E., Edgington, L. V., and Ripley, B. D. 1984. Bioactivity of the fungicide metalaxyl in potato tubers against some species of Phytophthora, Fusarium, and Alternaria, related to polyphenoloxidase activity. Can. J. Plant Pathol. 6:304-308.

2. Blodgett, E. C. 1945. Water rot of potatoes. Plant Dis. Rep. 29:124-126.

3. Blodgett, E. C., and Ray, W. W. 1945. Leak caused by Pythium debaryanum Hesse, produces typical shell rot of potatoes in Idaho. Am. Potato J. 22:250-253.

4. Bruin, G. C. A., Edgington, L. V., and Ripley, B. D. 1982. Bioactivity of the fungicide metalaxyl in potato tubers after foliar sprays. Can. J. Plant Pathol. 4:353-356.

5. Fry, W. E., Goodwin, S. B., Matuszak, J. M., Spielman, L. J., Migroom, M. G., and Drenth, A. 1992. Population genetics and intercontinental migrations of Phytophthora infestans. Annu. Rev. Phytopathol. 30:107-129.

6. Goodwin, S. B., and McGrath, M. T. 1995. Insensitivity to metalaxyl among isolates of Phytophthora erythroseptica causing pink rot of potato in New York. Plant Dis. 79:967.

7. Goss, R. W. 1949. Pink rot of potato caused by Phytophthora erythroseptica Pethyb. University of Nebraska, College of Agriculture, Agricultural Experiment Station, Lincoln, NE. Res. Bull. 160.

8. Hawkins, L. A., and Harvey, R. B. 1919. Physiological study of the parasitism of $P y$ thium debaryanum Hesse on the potato tuber. J. Agric. Res. 18:275-303.

9. Jones, W. 1935. Soft rot of potatoes caused by Pythium ultimum Trow. Sci. Agric. 15:402-410.

10. Lambert, D. H., and Salas, B. 1994. Metalaxyl insensitivity of Phytophthora erythroseptica isolates causing pink rot of potato in Maine. Plant Dis. 78:1010.

11. Lambert, D. H., and Salas, B. 2001. Pink rot. Pages 33-34 in: Compendium of Potato Diseases, 2nd ed. W. R. Stevenson, R. Loria, G. D. Franc, and D. P. Weingartner, eds. American Phytopathological Society, St. Paul, MN.

12. Lonsdale, D., Cunliffe, C., and Epton, H. A. S. 1980. Possible routes of entry of Phytophthora erythroseptica Pethyb. and its growth within potato plants. Phytopathol. Z. 97:109-117.

13. Millikin, G. A., and Johnson, D. E. 1992. Oneway treatment structure in a completely randomized design with heterogeneous errors. Pages 16-28 in: Analysis of Messy Data. Vol. 1: Designed Experiments. Chapman and Hall, London.
14. Mulrooney, R. P., and Gregory, N. F. 2001 Evaluation of foliar and soil applied fungicides for the control of pink rot of potato, 2000 . Fungic. Nematicide Tests 56:49.

15. Mulrooney, R. P., and Gregory, N. F. 2002. Evaluation of foliar and soil applied fungicides for the control of pink rot of potato, 2001. Fungic. Nematicide Tests 57:66.

16. Peters, R. D., Sturz, A. V., and Arsenault, W. J. 2003. Use of mefenoxam to control pink rot (Phytophthora erythroseptica) of potato in Prince Edward Island. Can. J. Plant Pathol. 25:33-40

17. Pethybridge, G.-H. 1913. On the rotting of potato tubers by a new species of Phytophthora having a method of sexual reproduction hitherto undescribed. Sci. Proc. Roy. Dublin Soc. 13:529-565.

18. Powelson, M. L., Johnson, K. B., and Rowe, R. C. 1993. Management of diseases caused by soilborne pathogens. Pages 149-158 in: Potato Health Management. R. C. Rowe, ed. American Phytopathological Society, St. Paul, MN.

19. Salas, B., and Secor, G. A. 2001. Leak. Pages 30-31 in: Compendium of Potato Diseases, 2nd ed. W. R. Stevenson, R. Loria, G. D. Franc, and D. P. Weingartner, eds. American Phytopathological Society, St. Paul, MN.

20. Salas, B., Secor, G. A., Taylor, R. J., and Gudmestad, N. C. 2003. Assessment of resistance of tubers of potato cultivars to Phytophthora erythroseptica and Pythium ultimum. Plant Dis. 87:91-97.

21. Salas, B., Stack, R. W., Secor, G. A., and Gudmestad, N. C. 2000. The effect of wounding, temperature, and inoculum on the development of pink rot of potatoes caused by Phytophthora erythroseptica. Plant Dis. 84:1327-1333.

22. Secor, G. A., and Gudmestad, N. C. 1999. Managing fungal diseases of potato. Can. J. Plant Pathol. 21:213-221.

23. Stamps, D. J., Waterhouse, G. M., Newhook, F. J., and Hall, G. S. 1990. Revised tabular key to the species of Phytophthora. Mycol. Pap., No. 162. C.A.B. International Mycological Institute.

24. Taylor, R. J., Salas, B., Secor, G. A., Rivera, V., and Gudmestad, N. C. 2002. Sensitivity of North American isolates of Phytophthora erythroseptica and Pythium ultimum to mefenoxam (metalaxyl). Plant Dis. 86:797-802.

25. Torres, H., Martin, C., and Henfling, J. 1985. Chemical control of pink rot of potato (Phytophthora erythroseptica Pethyb.). Am. Potato J. 62:355-361.

26. Van der Plaats-Niterink, A. J. 1981. Monograph of the genus Pythium. Stud. Mycol. 21:1-242.

27. Vujicic, R., and Colhoun, J. 1966. Asexual reproduction in Phytophthora erythroseptica. Trans. Br. Mycol. Soc. 49:245-254.

28. Wicks, T. J., Davoren, C. W., and Hall, B. H. 2000. Fungicidal control of Phytophthora erythroseptica: The cause of pink rot on potato. Am. J. Potato Res. 77:233-240.

29. Zink, R. T. 1995. The effect of metalaxyl on the incidence of pink rot. (Abstr.) Am. Potato J. 72:665-666. 